Article

\title{
Global Capital, Local Conservation, and Ecological Civilization: The Tiejia Ecology Temple and the Chinese Daoist Association's Green Agenda
}

\author{
Jennifer Lemche ${ }^{1}$ and James Miller ${ }^{2, *(\mathbb{D})}$ \\ 1 Cultural Studies Program, Queen's University, Kingston, ON K7L3N6, Canada; jennifer.lemche@queensu.ca \\ 2 Arts and Humanities Division, Duke Kunshan University, Kunshan 215316, China \\ * Correspondence: j.e.miller@dukekunshan.edu.cn
}

Received: 31 August 2019; Accepted: 14 October 2019; Published: 17 October 2019

check for updates

\begin{abstract}
Since 1995, the Chinese Daoist Association (CDA) has pursued a green agenda through the publication of declarations, statements and an eight year plan. This agenda has been aided in part by its engagement with global environmental discourse as mediated in particular by the Alliance for Religions and Conservation (ARC). Through its collaboration with ARC and a Dutch businessman, Allerd Stikker, the CDA built its first "ecology temple" in Shaanxi Province and convened its first ecological conference there. Analysis of these declarations and activities reveals an increasing globalization and juridification of environmental discourse in Chinese Daoist temples. In this way the issue of ecology presents further opportunities for the CDA, and by extension the Communist Party of China (CPC), to enhance their supervision of local religious activities.
\end{abstract}

Keywords: Daoism; ecology; conservation; ecological civilization

\section{Introduction}

Deep in the heart of the Heihe National Forest Park in Shaanxi province lies something of a curiosity. The Tiejia Ecology Temple is a Daoist temple and Ecology Center nestled at the foot of Mt. Taibai in a small forest clearing. The Heihe National Forest Park is about 80 kilometers to the southwest of Xi' an on the north side of the Qinling mountains and is home to a diverse range of species, most notably the giant panda. The drive to Tiejia Ecology Temple is about an hour from the main entrance of the park, down a narrow, winding dirt road that hugs the edge of the river, often in the shadow of looming mountains. The forest scenery only occasionally gives way to buildings and small villages. The Tiejia Ecology Temple shares its grounds with the World Wildlife Fund's Panda Lodges, an eco-resort constructed, according to Stikker (2014, p. 64), to promote sustainable tourism in the park and provide financial support for the nearby panda reserve. In the summer months, visitors flock to the area to hike the mountain trails and catch a glimpse of the pandas in their natural habitat. The area has long been considered sacred, due in large part to the Tiejiashu, an ancient sacred tree that managed to escape the ravages of the Cultural Revolution. The temple that accompanied it, however, was not so fortunate and was almost completely destroyed. The temple was rebuilt by the local people but an even newer temple, the Ecology temple, was built several years after that. That there should be a temple in this place is not all that surprising. That it should be a temple sponsored by the CDA and dedicated to teaching ecological values requires further analysis.

The Ecology Temple differs substantially from other Daoist temples, particularly those found in more urban areas. The temple itself is quite modest and houses three gods, the main gods of Taibaishan, themselves quite modestly adorned and flanked by several smaller figures. Other than the small piece of cloth hung directly above each of their heads, the wood beams of the roof are exposed along with 
the concrete walls. Two murals on the side walls tell the story of the Taibaishan gods. The temple houses a single incense burner, which, when examined more closely, serves to deepen the mystery of this unique temple. The inscription, both in English and Chinese, dedicates the burner to a woman named Anneke Dorina Stikker, who passed away in 2004. Anneke Stikker was the daughter of Dutch businessman Allerd Stikker, the head of the Valley Foundation, a private charitable organization that was instrumental in supporting and funding the construction of the ecology temple.

\section{The Chinese Daoist Association's Green Agenda}

Since its first official statement on ecology in 1995, the Chinese Daoist Association (CDA) has issued a variety of statements and declarations regarding their interpretation of the ecological crisis as well as measures they are taking to combat it. Initially, the statements broadly outlined a concern with the current worldview and the ecological crisis through the lens of Daoism's unique interpretation of the role of humanity in the natural world. After a few years, the statements matured into more concrete proposals, outlining detailed plans to create sustainable temples and curb the impact of religious tourism. One of the main tenets of their environmental plan was to bring about widespread education in sustainable practices to people all over China. The main statements are as follows:

1. The Declaration of the Chinese Daoist Association on Global Ecology (1995)

2. The Daoist Faith Statement, (2003)

3. The Qinling Declaration, (2006)

4. The Maoshan Declaration (2008)

5. The Eight Year Plan (2008)

The CDA attributes the current ecological crisis to the flawed worldview of the modern era. The 2003 Daoist Faith Statement summarizes the problem as follows: The problem of the environment not only is brought about by modern industry and technology, but also has a deep connection with people's world outlook, with their sense of value, and with the way they structure knowledge. Some people's ways of thinking have, in certain ways, unbalanced the harmonious relationship between human beings and nature, and overstressed the power and influence of the human will. People think that nature can be rapaciously exploited (see http://www.arcworld.org/faiths.asp?pageID=70; accessed December 1, 2018).

The 2003 Daoist Faith Statement builds on the earlier 1995 statement, reprinted with commentary from Zhang Jiyu 张继禹, sixty-fifth generation descendant of the first Celestial Master Zhang Daoling and former vice president of the CDA in Daoism and Ecology: Ways Within a Cosmic Landscape in 2001 (Zhang 2001) under the title "A Declaration of the Chinese Daoist Association on Global Ecology." This statement finds fault with the modern understanding of humanity as a separate and distinct category from the non-human world. This vision of the world has led to an abuse of the natural world and an expectation that the world's resources are limitless and for the sole benefit of human progress. Humanity views itself as the dominant species on the planet and has used this power to systematically destroy the ecological balance that allows life to thrive (Zhang 2001, p. 364). Zhang (2001, p. 365) further noted that "the ancient doctrines of Daoism are eminently able to remedy the deficiencies caused by the contemporary ethical theories." The 1995 statement continued by making the following assertions (Zhang 2001, p. 370):

We shall spread the ecological teachings of Daoism, lead all Daoist followers to abide in the teachings of self-so or non-action, observe the injunction against killing for amusement purposes, preserve and protect the harmonious relationship of all things with Nature, establish paradises of immortals on Earth, and pursue the practice of our beliefs ...

We will raise the awareness regarding ecology among various soial groups, resist the human exploitation of Nature and the abuse of natural environments, protect the earth upon which human survival depends, and generally make the world a better place for humans to inhabit. 
This initial statement showed the CDA's commitment to leading an environmental movement based on traditional Daoist beliefs. It likewise indicated an intention for all Daoists to follow the environmental agenda but also strikes a more evangelizing tone that aims to educate people outside of the Daoist community. Zhang (2001, p. 370) noted that since the release of the statement, the CDA has been contacted by several international organizations indicating an interest in cooperating with them and promoting their message abroad. He further commented that "present-day Daoists in China have diligently worked toward disseminating Daoist teachings and in maintaining the famous Daoist mountains and hermitages, planting trees and cultivating forests, and protecting the natural environment" (p. 371). The discourse presented in Zhang's commentary and the subsequent statements and declarations suggested a widespread ecological movement sweeping across the Daoist community and, even extending beyond it both to the larger Chinese society and the international community.

In 2003, the CDA produced the Daoist Faith Statement, a longer document than the 1995 declaration that outlined what they considered to be the core ecological teachings of Daoism and specifically highlighted four main principles: Dao fa ziran (Dao follows its natural spontaneity); the harmony of yin and yang; the limits of nature's sustaining power; and species diversity as a measure of affluence and environmental health (ARC 2003). In writing about the motivations of the CDA in designing and implementing a green agenda, Zhang (2001, p. 362) noted that "Daoism, like other great religions of the world, has a religious ideology that reflects its worldview, moral precepts, and ultimate concerns. Due to its close association with Chinese culture, Daoism has characteristics different from other religious traditions." He identified these defining characteristics as "Respecting Dao and Greatly Valuing De" and "The Way of Immortality Gives High Value to Life" (p. 365). These two key elements are not surprisingly also highlighted in the Daoist Faith Statement. The Faith Statement similarly asserted the Dao as the origin of everything and the importance of pursing immortality in valuing all life. Zhang (p. 362) understands "Respecting Dao and Greatly Valuing De" in the following way: "A Daoist believes in Dao, relies upon Dao, cultivates Dao, and practices Dao. De refers to the particular conduct of the believer as she practices Dao. One may say that de is the practice of Dao in the believer's life." Intimately bound up in this idea are the concepts of ziran and wuwei. Ziran in this context is understood as the natural state of each being and allowing all things to develop according to their own nature. Wuwei is precisely non-interference in this development. These two concepts form the principle of the Dao, which as Zhang (p. 362) noted "implies purity, tranquility, and simplicity, as well as softness and noncombativeness - the spirit of humility or vacuity as expressed by the image of the valley."

Zhang's second identifying factor, also noted in the Daoist Faith Statement, is the pursuit of immortality, a rather unique Daoist concept. Zhang noted that the Daoists' "ultimate goal is to let their lives and spirits become one with the Dao-the way of immortality-(xiandao). This is the reason why Daoists treasure life and value it as the most worthy thing on Earth." Similarly, the Daoist Faith Statement also extols the virtues of the pursuit of immortality, asserting its role in keeping individuals in good health and providing a certain level of youthfulness. The Faith Statement stresses, however, that there is one key component, "one point that cannot be neglected: a peaceful and harmonious natural environment is a very important external condition."

These two concepts form the underlying framework for the CDA's understanding of the universe and the larger role that humanity plays in the cosmological order. More importantly, the emphasis on these two concepts in the CDA's green agenda projects a very specific image of Daoism. Both concepts stress the natural world and lack strong supernatural elements. The elevation of the importance of life and the natural order is most clearly visible in the discussion of immortality, which rather than discussing the supernatural realm, stresses the benefits for the health of the body. Daoism, represented in this light, becomes a life affirming tradition that prioritizes the natural environment. The CDA, in constructing their green agenda, chose to emphasize the components of the tradition that speak directly to an ecological ethic.

The Daoist Faith Statement highlights four main principles that elucidate Daoism's inherent ecological characteristics. The first, which derives from chapter 25 of the Daode jing, states: "Humanity 
follows the Earth, the Earth follows Heaven, Heaven follows the Dao, and the Dao follows what is natural." This rather esoteric statement is explained in the Daoist Faith Statement which notes that "[w]e should cultivate in people's minds the way of no action in relation to nature, and let nature be itself." The former president of the CDA, Ren Farong, expressed similar sentiments while speaking about Daoism at world conferences: "just imagine all local wars, regional conflicts and environmental degradation in the world are caused by human errors. Therefore, Taoism advocates governing by doing nothing that goes against nature" (qtd. in Xie 2008). Ren's sentiments suggest that the underlying natural processes of the world already possess a wisdom that should command respect from human beings. Both Ren and the Daoist Faith Statement offer up an image of Daoism that is largely couched in humanist, almost secular terminology, a tactic that pervades the Faith Statement and the CDA's green agenda in general.

The second component that stresses the inherent ecological qualities of Daoism is found in the concept of yin and yang. As noted in the above discussion of yin and yang, the cosmos and everything in it, are comprised of two complementary forces, known as Yin and Yang. Yin evokes the cold, soft, dark qualities while yang evokes the hot, hard and bright. The Faith Statement highlights the importance of these two forces in noting that they "are in constant struggle within everything. When they reach harmony, the energy of life is created. From this we can see how important harmony is to nature." The Faith Statement extrapolates this understanding of the universe to create the basis of an environmental ethic in averring "Those who have only a superficial understanding of the relationship between humanity and nature will recklessly exploit nature. Those who have a deep understanding of the relationship will treat nature well and learn from it." While there is an emphasis on the role of human beings within the natural world the statement also expands this cosmological worldview into a secular mandate for environmentalism that speaks to a conservation of resources and a general respect of the balance of natural environments.

The third component stresses the importance of balance in nature. The Faith Statement notes "If anything runs counter to the harmony and balance of nature, even if it is of great immediate interest and profit, people should restrain themselves from doing it, so as to prevent nature's punishment."

Finally, the fourth component, and perhaps the aspect most in line with current environmental paradigms, stresses the importance of biodiversity. The Faith Statement notes that Daoism "judges affluence by the number of different species" present in the world and encourages governments and people to take good care of nature." This particular understanding of biodiversity comes from a lesser known classical Daoist text, the Taiping jing, which refers to three notable periods in the historical trajectory of life on earth. The first, the Higher August Period, sees 12,000 species flourish on earth. The Middle August Period witnesses a decline in the diversity of species living on earth and the Lower August Period, known also as the Era of Great Poverty, sees a drastic decline in the level of species diversity and signals the arrival of an era known as Extreme Poverty. Zhang (2001, p. 368) noted that "because the Lower August Period the earth is not given proper nourishment and is greatly injured by its inhabitants, it produces fewer living things."

Following the 2003 declarations, the CDA with the support of Alliance for Religions and Conservation (ARC) and Stikker's Valley Management Fund constructed the ecology temple in Shaanxi province. According to the (now defunct) ARC website, the temple and adjacent ecology center were built using all local materials by a construction crew sourced from the local towns and who were, according to ARC (2007), held to a "higher ethical standard." The Ecology Temple hosted the first two Daoist ecology conferences in 2006 and 2007, co-sponsored by the CDA, ARC and the Valley Foundation. The first ecology conference in 2006 was attended by fourteen Daoist monks and nuns from ten different monasteries from Shaanxi and Gansu provinces and introduced them to sustainable practices. The 2006 conference gave rise to the Qinling Declaration and in 2007, the Ecology Temple was officially consecrated. 
The Qinling Declaration outlined the following sustainability goals:

1. reduce pollution caused by incense burners

2. use farm land sustainably

3. protect species and forests

4. save energy

5. protect water resources

The Qinling Declaration represents the first step by the Daoist to move towards more practical goals rather than simply outlining tenets of the faith that lend themselves to an ecological sensibility. Also in attendance at the 2006 conference were: Martin Palmer, director of ARC; Allerd Stikker, head of the Valley Foundation; and Professor Fan Guangchun, Director of the Daoist Studies Institute at Shaanxi Academy of Social Sciences.

The following year, in 2007, the second ecology conference took place alongside the consecration ceremony for the ecology temple and its adjoining ecology center. This second conference saw a dramatic increase in interested participants. ARC (2007) reported that eighteen monks and nuns participated but many more were turned away due to lack of space. These attendees created the Daoist Temple Alliance during the conference which aimed to create an ecology program that teaches and promotes an ecological agenda. Members of the Alliance agreed to display a copy of the Qinling Declaration in their temples to help educate visitors in sustainability and to progress towards transforming all Daoist temples into ecology temples (He 2007). In order to do so, they determined that all temples should conduct a survey of their environmental impact. These environmental impacts studies were designed to show where temples could improve on their ecological footprint. Each temple was provided with a checklist, which was measured against the official definition of an ecology temple that was also decided upon at the 2007 conference:

1. A temple that has been planned and constructed according to Daoist teaching with the basic religious function of promoting the Daoist faith and which promotes the sage Laozi as the God of Ecological Protection;

2. A temple that uses the resources of land, forest, water, and earth, to green and beautify its surrounding landscape;

3. A temple with facilities to protect water sources and sewage treatment with regulations on sanitation and fire protection;

4. A temple that is using alternative energy technology and materials to use energy wisely;

5. A temple that has a harmonious relationship with the surrounding environment and communities

6. A temple that in itself is a base for education about the environment and ecology He (2007)

Along with audits of the sustainability of their respective temples, attendees discussed the impact of certain projects that had already been put in place to "green" temples and their grounds. Some of the measures being considered were: installing solar panels on temple roofs, recycling water, installing clean toilets, joining together to buy eco-friendly incense, reducing the impact of nationwide shipping and bringing land use and management of the temple into the ecological protection planning of the surrounding area (He 2007). While the 2007 conference did not produce a statement on the environment as the 2006 and 2008 conferences did, it did produce the standard by which, theoretically, all Daoist temples were meant to measure themselves against. Not only did it create a very specific definition of an ecological temple, it also instituted temple surveys on sustainability and an alliance on ecological education, thereby extending the role of the CDA in the individual temples and promoting more environmentally sound practices.

Maoshan, the famous Daoist peak and location of the Shangqing revelations, hosted the third ecology conference in 2008. This conference was a notable departure from the previous two for two important reasons. First, it was not held at the ecology center, a remote location tucked away in the mountains of Shaanxi province but rather at a large, famous temple complex on a mountain in 
Jurong, Jiangsu province that also housed a military monument and was designated as a AAAA tourist destination. Second, the attendance grew from 18 monks and nuns to 69 and more importantly, one hundred and twenty government officials and high ranking UNDP representatives were also present (ARC 2008c). These figures are significant in showing that while the initial conferences appeared to be more of a small-scale grassroots movement, largely concerning a handful of Daoist temples in Shaanxi and Gansu, the CDA's green agenda had caught the attention of the government and appeared to have a certain degree of support and legitimacy on a national scale.

The Maoshan conference produced the Maoshan Declaration and Eight Year Plan. The language of these two newer documents showed even more focus on practical solutions to environmental challenges. Those signing the Maoshan Declaration made the following commitments (ARC 2008b):

1. Putting great effort into ecological education and training. expanding materials and education about the natural environment, that will be open to pilgrims and ordinary temples and mountains.

2. Advocating simpler lifestyles that will reduce energy and energy costs.

3. Participating in social environmental activities with the community.

4. To enhance cooperation with the media to spread the word about ecology.

5. To build ecological temples as our duty.

6. Maximizing the ecological benefit we can achieve from our assets.

7. Building and maintaining a Daoist Ecological Protection Network

This document showed a clear departure from the earlier documents, which focused solely on the elements of the Daoist faith that lent themselves to an ecological sensibility. The Maoshan Declaration showed a deeper engagement with concepts of sustainability, with society, and with the international community. The Eight Year Plan demonstrated even more of a commitment to sustainable practices and outlined very detailed plans for Daoist temples to become not only models of sustainability but also places synonymous with sustainable education.

The Eight Year Plan represented a significant departure from the previous statements and declarations by presenting a detailed approach to sustainable engagement and a serious commitment to an ecological agenda for all Daoist temples (ARC 2008a). It further suggested a sustained and long-term effort on the part of the CDA to urge the Daoist faith in the direction of environmental activism and sustainability. One of the ways the CDA managed to impose a more uniform practice on what had traditionally been a disparate religious tradition was to create sweeping regulations that transcended the role of individual temples. The first step was to ban the use of endangered animals in Traditional Chinese Medicine (TCM) and make any violation an excommunicable offense (China Dialogue 2006). Part E of the second section of the Eight Year Plan, "Public Welfare and Charity" explicitly states that endangered animals and plants are prohibited for use in practices related to healthcare, cooking, or medicinal remedies.

A second step concerned resource management. In Part C, Pilgrims and Travel, temples are called on to provide a "healthier and more environmentally friendly style of pilgrimage and travel," stressing the practice of "three stick incense burning." Three sticks are enough is another signature campaign of ARC in Asia that aims to reduce the amount of incense being burned at temples. Visitors to temples are encouraged to burn only three sticks of incense and ideally to use the eco-friendly incense provided. The Eight Year Plan endorsed the three sticks program to curb excessive burning of incense traditionally a part of Daoist temple ritual with the stated aim being to "reduce pollution caused by burning incense, candles, papers and fireworks on Daoist premises." As an alternative, the Eight Year Plan suggested offerings of flowers and fruit, with the added caveat that they be sustainably sourced (see (Jackson 2010) for an interesting discussion on the impact of food offerings on local economies in Taiwan).

The Eight Year Plan, along with the other statements and declarations mentioned above, highlight specific elements of the CDA's environmental agenda including resource management, conservation, 
and energy saving. Additionally, they showcase the aspects of the Daoist tradition that provide the basis for Daoism being understood as an ecological religion.

\section{Ecology and Globalization}

Two key themes stand out in this history of the Chinese Daoist Association's pursuit of a green agenda. The first is the role of international agencies such as ARC and the Valley Management Foundation in helping to work with and promote the CDA's efforts in producing a green agenda. The second is the increasing important of ecological juridifcation, the creation of environmental laws as a means to assert central authority over local practice.

\subsection{The Role of International Agencies}

The Alliance for Religion and Conservation (ARC) led by Martin Palmer, was founded by Prince Philip in 1995 when he convened a meeting of leading conservation groups and nine world religions at Windsor Castle in England, the aim of which was "to link the secular worlds of conservation and ecology with the faith worlds of the major religions." (ARC n.d.). Ten years prior to this, Prince Philip, as head of the World Wild Life Fund for Nature (WWF) had organized a meeting between leaders of the world's largest religions and several environmental organizations to discuss the role that faith could play in address growing ecological problems. The organizers of the Assisi conference stressed the value of cultural diversity with a special invitation to all participants to "Come, proud of your own tradition but humble enough to learn from others" (ARC n.d.). With funding largely from the World Bank, ARC sought to bring a global environmental agenda to the world's major faith traditions, including the Chinese Daoist Association, a particular interest of Palmer. The development of a green agenda by the CDA can be seen as the fruitful engagement between a local religious tradition, one not widely known or understood even in China, let alone abroad, with a global environmental NGO. Indeed, the ARC website, though now defunct, was a major regular source of English-language information about the ongoing activities of the Chinese Daoist Association, and of course served to highlight the CDA's ecological activities.

The CDA's green agenda, however, would have been unlikely to achieve concrete results without the inspiration and financing of Allerd Stikker and the Valley Management Foundation, who played an instrumental role in the concrete realization of the goal of producing a model "ecology temple" within the Heihe National Park. The ecology temple stands as the first practical example of what the CDA's green agenda might actually look like and gave a real impetus to the production of laws, guidelines and statements over the next decade. That the first Daoist ecology temple in China was realized principally through a Chinese-UK-Dutch partnership stands as testament to the role played by global actors and global capital in the practical development of the Chinese Daoist Association's environmental agenda.

The CDA's green agenda thus relied in part on the expertise and financing of global instructions and actors. At the same time, analysis of the CDA's documents reveals a gradual shift away from the formulation of unique Daoist values and concepts regarding environmental and ecological issues, towards a focus on more practical and more globally recognizable concerns such as environmental education, energy conservation, and biodiversity preservation. A question that arises from this is whether this shift is partly the result of the CDA's engagement with global environmental actors, or whether this reflects changes within the domestic environmental policy situation in China. That is to say, is the CDA's focus on more generic and less uniquely Daoist formulations of environmental policy the result of its engagement with ARC (or other global agencies)?

As Miller (2017) has noted, environmental communication in China has tended to adopt a global scientific discourse of environmental concepts and principles, rather than favoring their reworking or reformulation in traditional Chinese terms. Indeed, as Yeh (2013) has amply demonstrated, the disjunction of global environmental goals and local traditions has produced miscommunication and even failure of environmental projects. 


\subsection{Environment and Juridification}

The second point to be made about the involvement of ARC and the CDA thus draws on the issue of juridification. The environmental agenda pursued by the CDA took the form of a top-down initiative designed to be applied more or less uniformly across temples in China. The ecological declarations and statements of the CDA make repeated references to overarching policies such as restrictions on incense burning, banning endangered species from being used in Traditional Chinese Medicine practices and injunctions to make all temples ecological temples. Together, we can theorize that the environmental agenda developed in partnership with ARC contributed to the development of a religious policy discourse focused principally on the good governance and management of temples.

Through the evolution of the CDA's environmental discourse we can observe a shift from a focus on aspects of the Daoist tradition that suggested an underlying environmental ethic to adopting a program more akin to international standards on sustainability, such as renewable resources, recycling, and eco-friendly incense, among others. This shift can be understood as a shift from conceptual and ethical priorities to ones of implementation and governance. They align, however, with the broader agenda of the CDA in establishing its national authority over local forms of worship and practice, thus contributing to the CPC's overarching goal of establishing a unified national system for the guidance and management of religious activities by the Party.

\section{Towards an Ecological Civilization}

One of China's key national development goals, the term ecological civilization (shengtai wenming) denotes in China a post-industrial stage of economic development, one that through the use of advanced technology, centralized planning, and government incentive reduces the negative environmental impact of traditional capitalist economic development. Goron (2018, p. 41) identifies ecological civilization firstly as a "political response to the state's failure to protect the environment," but the term did not achieve full prominence until 2012 when it was enshrined in the report of the 18th Party congress. In discussing why China did not adopt the more widely-known term "sustainable development" Goron (p. 42) notes that the term ecological civilization was born in part from an internal Chinese eco-marxist critique of neoliberal economic development models, and a desire to reject "binding environmental norms as disguised western imperialsm." That is to say, the development of the concept of ecological civilization grew out of China's internal efforts to develop its own strategy for environmental issues, one that was rooted in traditional Chinese cultural values, and one that would later play a key role in President Xi Jinping's ideology of national rejuvenation. In Goron's analysis, therefore, the adoption of a language of ecological civilization can be understood as part of the China's transformation from the early 2000s Hu Jintao era of "scientific development" towards one in which cultural values, and the promotion of Chinese national identity, would come to dominate the ideological sphere.

In such a climate, therefore, it is no wonder that Chinese Daoist Association has sought to play a key role in the cultural architecture of ecological civilization. As China's only indigenous religion, it has seen for itself the possibility of a rebirth under the ideological aegis of Xi Jinping thought. Thus the movement towards an ecological civilization is occurring at the same time as renewed interest in China's traditional cultures and religions in China. Paradoxically perhaps, in the Xi Jinping era, the push towards economic and technological innovation functions in close relation to a resurgence of cultural tradition. This has usually been theorized in terms of the development of a form of economic nationalism. China's technological innovation is presented as a way to disentangle itself from the specter of Western values, and to promote the resurgence of a renewed, national character. At the same time, however, notion of an ecological civilization implies at the very least a questioning of the values and logics of modernity, including the social imagination of nature as inert matter subject only to economic exploitation. Here at least the attempt of the CDA to promote Daoism as a kind of "green religion" is enabled not only by aligning with the calls for a more nationalist economic policy, but also by a deeper questioning of the values of modernity, especially a Euro-American modernity, that, through the combination of capitalist profit-seeking and colonial domination, has abetted the 
despoliation of nature across the world. In such a climate it is no wonder that the long-cherished Daoist values of naturalness and simplicity should rise to the fore.

The possibility for Daoism's rebirth as a green religion, however, occurs precisely at the same time as the increased juridical control of China's religions. One arena in which this process of juridification in China is taking place is that of ecology and environment. Top-down environmental initiatives promoted by the Chinese Daoist Association may reasonably be seen as a further stage in the transformation in the relationship between the central state and local religions, one that continues China's long process of attempting to normalize, regularize and manage all forms of religious activity within its borders. In this sense the development of an ecological civilization holds nothing new in terms of the history of religion in modern China: it presents just another opportunity for the state to exercise authority over local traditions.

How then to understand the legacy of Allerd Stikker, the Alliance for Religions and Conservation, and the first Ecology Temple in Shaanxi? Firstly, this legacy demonstrates that the arena of ecology and environment is one that has enabled the engagement of Daoism and the West. Reaching back to the New Age era, and through the projection of Orientalist fantasies, Daoism has always stood in the Western social imagination an antidote to Western modernity. Favoring nature rather than technology, and the local over the global, Daoism has long been imagined as the radical hope that Chinese culture possesses a wisdom that goes beyond the limits of Western thinking. As LaChapelle (1988, p. 90) famously claimed in her "extended rhapsody," Sacred Land, Sacred Sex-Rapture of the Deep: "Now after all these years of gradual, deepening understanding of the Taoist way, I can state categorically that all these frantic last-minute efforts of our Western world to latch on to some 'new idea' for saving the earth are unnecessary. It's been done for us already-thousands of years ago-by the Taoists." There is no doubt that the global promotion of Daoism as a green religion has been aided and abetted by this social imagination.

While the CDA's green agenda was undoubtedly aided by Western imagination about Daoist religion, this has not resulted in the wholesale globalization of Daoism as a religious tradition, or ecology as a global agenda. As Palmer and Siegler (2017) have wryly observed, the entanglement of Western imaginings about Daoism with indigenous Chinese realities is one that does not solely produce misunderstanding, but even unexpected affinities and positive engagements. In this case, the development of Daoism's green agenda is one that has been redirected along the lines of an indigenously Chinese ecological civilization under the clear leadership of the Party and with the goal of national rejuvenation. At a recent visit to a Daoist temple near Chongqing, Miller observed three banners decorating the entrance: the first promoted the ecocentric notion of an inter-related community of humans and nature (ren yu daziran shi yizhong gongsheng guanxi); the second promoted a month devoted to studying the religious policies and regulations; the third offered the local Daoist association's congratulations on the seventieth anniversary of the founding of the People's Republic of China. While global capital and international NGOs may have helped bring about the birth of Daoism's green agenda, Daoism's key public messages today are ecology, religious regulation and national rejuvenation. All three themes are woven into the fabric of the ideology of ecological civilization in the Xi Jinping era.

Author Contributions: Conceptualization, J.L.; Methodology, J.L.; Formal Analysis, J.L. and J.M.; Investigation, J.L.; Data Curation, J.L.; Writing-Original Draft Preparation, J.L.; Writing-Review \& Editing, J.M.; Supervision, J.M.; Project Administration, J.L.

Funding: This research received no external funding.

Conflicts of Interest: The authors declare no conflict of interest. 


\section{References}

ARC. 2003. Daoist Faith Statement. Available online: http://www.arcworld.org/faiths.asp?pageID=70 (accessed on 1 December 2018).

ARC. 2007. Daoist Ecology Workshops Hugely Oversubscribed. Available online: http://www.arcworld.org/news. asp?pageID=171 (accessed on 1 December 2018).

ARC. 2008a. China Daoist Ecology Protection Eight Year Plan. Available online: http://www.arcworld.org/ downloads/Daoist\%20Eight\%20Year\%20Plan\%2008-10-31.pdf (accessed on 1 June 2019).

ARC. 2008b. The Mao Shan Declaration. October. Available online: http://www.arcworld.org/projects.asp? projectID=371 (accessed on 1 December 2018).

ARC. 2008c. Third Daoist Ecology Forum Opens in Jurong, Jiangsu—And This One is Country-Wide. Available online: http://www.arcworld.org/news.asp?pageID=273 (accessed on 1 December 2018).

ARC. n.d. About ARC. Available online: http://www.arcworld.org/about_ARC.asp (accessed on 1 December 2018).

China Dialogue. 2006. Religion and the Environment in China. Available online: http://www.chinadialogue.net/ article/show/single/en/485-Religion-and-the-environment-in-China (accessed on 31 August 2019).

Goron, Coraline. 2018. Ecological Civilisation and the Limits of a Chinese Politics of Sustainability. China Perspectives 4: 39-52.

He, Xiaoxin. 2007. Taking Care of Nature: Building Up the Daoist Ecology Temple by Our Own Hands. Available online: http://www.arcworld.org/downloads/07\%20June\%20workshop\%20report.pdf (accessed on 31 August 2019).

Jackson, Paul. 2010. Don't Trample the Grass: Popular Daoism and Ecology in Taiwan. Paper presented at the 2010 Annual Conference on Daoist Studies, Los Angeles, CA, USA, June 2-6.

LaChapelle, Doris. 1988. Sacred Land, Sacred Sex-Rapture of the Deep: Concerning Deep Ecology and Celebrating Life. Silverton: Fine Hill Arts.

Miller, James. 2017. China's Green Religion: Daoism and the Quest for a Sustainable Future. New York: Columbia University Press.

Palmer, David A., and Elijah Siegler. 2017. Dream Trippers: Global Daoism and the Predicament of Modern Spirituality. Chicago: University of Chicago Press.

Stikker, Allerd. 2014. Sacred Mountains: How the Revival of Daoism Is Turning China's Ecological Recovery Around. London: Bene Factum Publishing.

Xie, Chuanjiao. 2008. Religious Leaders Call for Peace, Harmony. China Daily. October 28. Available online: http://www.chinadaily.com.cn/world/2008-10/28/content_7151569.htm (accessed on 31 August 2019).

Yeh, Emily. 2013. Taming Tibet: Landscape Transformation and the Gift of Chinese Development. Ithaca: Cornell University Press.

Zhang, Jiyu. 2001. A Declaration of the Chinese Daoist Association on Global Ecology. In Daoism and Ecology: Ways within a Cosmic Landscape. Edited by N. J. Girardot, James Miller and Xiaogan Liu. Cambridge: Harvard University Center for the Study of World Religions.

(C) 2019 by the authors. Licensee MDPI, Basel, Switzerland. This article is an open access article distributed under the terms and conditions of the Creative Commons Attribution (CC BY) license (http://creativecommons.org/licenses/by/4.0/). 